\title{
HYDROLYSIS OF CALCITE IN POTASSIUM PHOSPHATE SOLUTIONS
}

\author{
Shigeki Matsuya*, Koh-ichi Udoh, Masaharu Nakagawa, Kunio Ishikawa \\ (*Corresponding author: smatsuya@dent.kyushu-u.ax.jp) \\ Department of Biomaterials, Faculty of Dental Science, Kyushu University \\ 3-1-1 Maidashi, Higashiku, Fukuoka 812-8582, Japan
}

Key words: Calcite, Hydrolysis, Phosphate, Carbonated apatite

Abstract: Hydrolysis of calcite was investigated in $0.1 \mathrm{~mol} / \mathrm{L} \mathrm{KH} \mathrm{KH}_{4} / \mathrm{KH}_{2} \mathrm{PO}_{4}$ solutions with various pHs between 4.5 and 8.5 at $60^{\circ} \mathrm{C}$ by means of solution analyses $(\mathrm{pH}, \mathrm{Ca}$ and $\mathrm{P}$ concentrations), X-ray diffraction, Fourier-transformed infrared spectroscopy and scanning electron microscopy. Calcite was mostly hydrolyzed within several days and the final product was octacalcium phosphate (OCP) or apatite phase depending on their initial pHs. OCP was initially formed in the solution with lower $\mathrm{pH}$ and it was transformed into apatite phase with increasing in $\mathrm{pH}$. Calcite was directly transformed into apatite in 0.1 $\mathrm{mol} / \mathrm{L} \mathrm{K}_{2} \mathrm{HPO}_{4}$ solution with the highest initial $\mathrm{pH}$. These phenomena were probably related to solubility of apatite, OCP and calcite at $\mathrm{pH}$ during hydrolysis. FT-IR analysis showed that the apatite phase formed was B-type carbonated apatite, in which $\mathrm{CO}_{3}{ }^{2-}$ ion substituted for $\mathrm{PO}_{4}{ }^{3-}$ ion.

(Received June 30, 2004; Accepted August 25, 2004)

\section{INTRODUCTION}

Calcium carbonate in aragonite form is a main constituent of marine coral, of which skeleton structure is similar to human cancellous bone. The marine coral has been widely used as a bone filler for the deficient part of hard tissue, because it has an open pore structure suitable for penetration of osteoblast to enable a new bone formation and its resorbability. ${ }^{1}$ Marine coral can be converted into hydroxyapatite while preserving its porous skeleton structure by hydrothermal treatment in phosphate solution. $^{2-4}$ The product is called coralline apatite ${ }^{5}$ and it has been commercially available, for example, as Pro Osteon (Interpore Cross). In the hydrothermal treatment, calcium carbonate reacts with phosphate ion to form carbonated apatite, that is, hydroxyapatite containing carbonate ion in the lattice structure, though the reaction process has not been fully understood so far. There have been only a few studies on hydrolysis of $\mathrm{CaCO}_{3}$ itself related to carbonated apatite formation. Ames reported that carbonated apatite was formed by phosphate replacement of calcite in alkaline $\mathrm{Na}_{3} \mathrm{PO}_{4}$ solution. ${ }^{6}$ Later Simpson reported the effect of $\mathrm{pH}$ and phosphate concentration on the carbonated apatite formation from calcite and sodium phosphate solution. ${ }^{7}$ Monma and Takahashi reported carbonated apatite formation through the reaction of calcium hydrogen phosphate in the presence of $\mathrm{CaCO}_{3}{ }^{8}$ In the present study, hydrolysis of calcite was investigated in potassium phosphate solutions at different initial $\mathrm{pH}$ by $\mathrm{X}$-ray diffraction analysis, Fourier transform infrared spectroscopy and scanning electron microscopy.

\section{MATERIALS AND METHODS}

Commercially available calcium carbonate, $\mathrm{CaCO}_{3}$ was used without further purification. X-ray diffraction analysis showed that calcite was the only phase present and no other phase was found. Four kinds of potassium phosphate solutions were used for the experiment, that is, $0.1 \mathrm{~mol} / \mathrm{L} \mathrm{KH}_{2} \mathrm{PO}_{4}, 0.1 \mathrm{~mol} / \mathrm{L}$ $\mathrm{K}_{2} \mathrm{HPO}_{4}$ and their $2: 1$ and $1: 2$ mixed solutions. Measurement of $\mathrm{pH}$ was done at $60^{\circ} \mathrm{C}$ by using a $\mathrm{pH}$ meter (TOKO TPX-90, Tokyo, Japan) equipped with a glass electrode calibrated at $\mathrm{pH} \mathrm{4,7}$ and 9. Initial $\mathrm{pHs}$ of the solutions was $4.51\left(0.1 \mathrm{~mol} / \mathrm{L} \mathrm{KH}_{2} \mathrm{PO}_{4}\right)$, $8.44\left(0.1 \mathrm{~mol} / \mathrm{L} \mathrm{K}_{2} \mathrm{HPO}_{4}\right), 6.44$ (2:1 mixed solution) and 7.09 (1:2 mixed solution). About two grams of the calcite powder was put in $200 \mathrm{~mL}$ of each solution kept at $60^{\circ} \mathrm{C}$. The solution was magnetically stirred at about $300 \mathrm{rpm}$ during the reaction. The overall $\mathrm{Ca} / \mathrm{P}$ ratio in the system is 1 and the amount of $\mathrm{P}$ is about $80 \%$ in excess with respect to a $\mathrm{Ca} / \mathrm{P}$ ratio of 1.67 in stoichiometric hydroxyapatite, $\mathrm{Ca}_{5}\left(\mathrm{PO}_{4}\right)_{3} \mathrm{OH}$. After appropriate time intervals, $2 \mathrm{~mL}$ of the suspension was picked up from the solution and then filtrated through a $0.2 \mu \mathrm{m}$-membrane filter. The solid residue was washed with distilled water several times and finally with ethanol then dried at $80^{\circ} \mathrm{C}$. Analysis of the filtrate was also done on $\mathrm{pH}$ and concentration of $\mathrm{Ca}$, and $\mathrm{P}$. Calcium ion concentration was determined by an atomic absorption spectroscopy with $\mathrm{C}_{2} \mathrm{H}_{2} / \mathrm{N}_{2} \mathrm{O}$ flame (Aanalyst 300, PERKIN ELMER Co., Ltd., Kanagawa, Japan). Phosphate concentration was spectrophotometrically determined at $830 \mathrm{~nm}$ using phosphomolybdenum method. On the other hand, the dried residue was characterized by using X-ray diffraction (XRD) analysis, Fourier transform 
Matsuya S, Udoh K, Nakagawa M, Ishikawa I

infrared (FT-IR) spectroscopy, and scanning electron microscopic (SEM) observation. The XRD patterns of the specimens were recorded with a vertically mounted diffractometer system (RINT 2500V, Rigaku, Tokyo, Japan) using counter-monochromatized $\mathrm{CuK}_{\alpha}$ radiation generated at $40 \mathrm{kV}$ and $100 \mathrm{~mA}$. The specimens were scanned from $10^{\circ}$ to $60^{\circ}$ of $2 \theta$ in a continuous mode at a scanning rate of $2 \% \mathrm{~min}$. Lattice parameter of the final product phase was determined by WPPF (whole-powder-pattern fitting) program installed in the work station attached to the XRD equipment. FT-IR spectra were measured with a $\mathrm{KBr}$ disc method by using the FT-IR spectrometer (SPECTRUM 2000LX, PERKIN ELMER Co., Ltd., Norwalk, CT, USA). Scanning electron microscope (JSM 5400LV, JEOL Co., Ltd., Tokyo, Japan) was used for the observation of the morphology at an acceleration voltage of $15 \mathrm{kV}$ after gold coating.

\section{RESULTS AND DISCUSSION}

Figure 1 shows change in $\mathrm{pH}$ of each phosphate solution with time during hydrolysis of calcite. A rapid increase in $\mathrm{pH}$ from 4.5 to 7 was observed within $1 \mathrm{~h}$ after the start of reaction in $0.1 \mathrm{~mol} / \mathrm{L}$ $\mathrm{KH}_{2} \mathrm{PO}_{4}$ solution. Then $\mathrm{pH}$ began to increase rapidly again after $2 \mathrm{~h}$. Thus an increase in $\mathrm{pH}$ seemed to occur in two steps. The $\mathrm{pH}$ was kept around 9 between $8 \mathrm{~h}$ and $50 \mathrm{~h}$ and finally tended to decrease down to 8 . Similar changes in $\mathrm{pH}$ were also observed with the $2: 1$ and $1: 2$ solutions with medium initial $\mathrm{pH}$ of 6.5 and 7 though the initial rapid increase was not remarkable. With $0.1 \mathrm{~mol} / \mathrm{L} \mathrm{K}_{2} \mathrm{HPO}_{4}$ solution, which had the highest initial $\mathrm{pH}$ of $8.4, \mathrm{pH}$ increased up to 9.4 within $1 \mathrm{~h}$ and was kept constant during the hydrolysis.

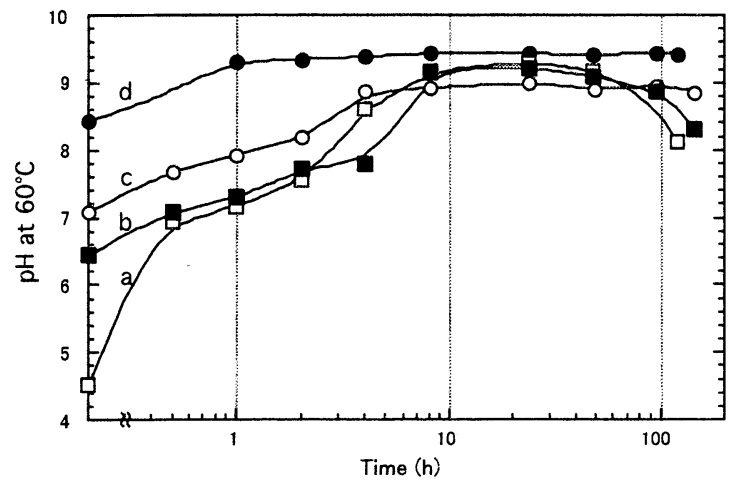

Figure 1 Change in $\mathrm{pH}$ of each phosphate solution with time during hydrolysis of calcite.

a: $0.1 \mathrm{~mol} / \mathrm{LKH}_{2} \mathrm{PO}_{4}$, b: $\mathrm{KH}_{2} \mathrm{PO}_{4} / \mathrm{K}_{2} \mathrm{HPO}_{4}=2 / 1$,

c: $\mathrm{KH}_{2} \mathrm{PO}_{4} / \mathrm{K}_{2} \mathrm{HPO}_{4}=1 / 2$, d: $0.1 \mathrm{~mol} / \mathrm{LK}_{2} \mathrm{HPO}_{4}$

Figure 2 shows change in $\mathrm{P}$ concentration with time during hydrolysis in the phosphate solutions.
With $0.1 \mathrm{~mol} / \mathrm{L} \quad \mathrm{KH}_{2} \mathrm{PO}_{4}$ solution, which had the lowest $\mathrm{pH}, \mathrm{P}$ concentration rapidly decreased within $30 \mathrm{~min}$. The initial rapid increase in $\mathrm{P}$ concentration corresponded to the initial $\mathrm{pH}$ decrease in the solution, as shown in Fig.1. With the increase in initial $\mathrm{pH}$ of the solutions, the rate of decrease in $\mathrm{P}$ concentration became smaller. The final $\mathrm{P}$ concentration decreased with the decrease in initial $\mathrm{pH}$ of the solution. This fact suggests that the amount of $\mathrm{P}$ absorbed in calcite was larger in the solution with lower initial $\mathrm{pH}$. This is caused by the difference in final product in those solutions, as described later.

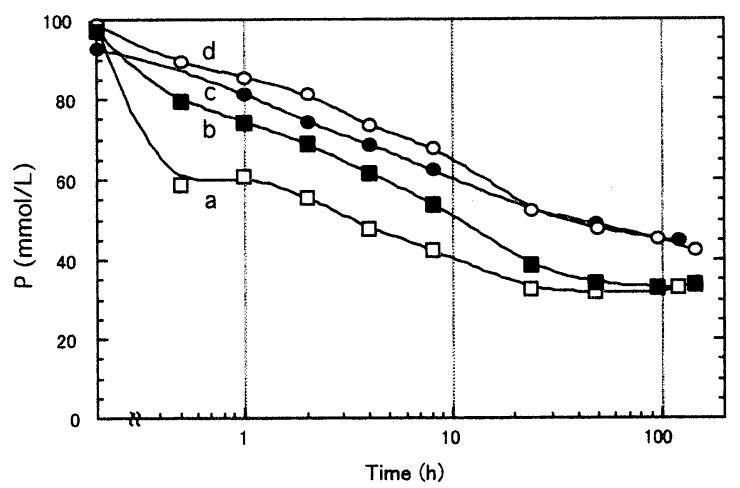

Figure 2 Change in $\mathrm{P}$ concentration with time during hydrolysis in the phosphate solutions.

$$
\begin{aligned}
& \text { a:0.1 mol/LKH } \mathrm{LO}_{2}, \mathrm{~b}: \mathrm{KH}_{2} \mathrm{PO}_{4} / \mathrm{K}_{2} \mathrm{HPO}_{4}=2 / 1 \text {, } \\
& \text { c: } \mathrm{KH}_{2} \mathrm{PO}_{4} / \mathrm{K}_{2} \mathrm{HPO}_{4}=1 / 2 \text {, d: } 0.1 \mathrm{~mol} / \mathrm{LK}_{2} \mathrm{HPO}_{4}
\end{aligned}
$$

Figure 3 shows change in $\mathrm{Ca}$ concentration with time during hydrolysis in the phosphate solutions. Calcium concentration showed maximum between 3 and $5 \mathrm{ppm}$ within $30 \mathrm{~min}$ and then gradually decreased down to $0.1-0.4 \mathrm{ppm}$ in the phosphate solutions except for in $0.1 \mathrm{~mol} / \mathrm{L} \mathrm{K}_{2} \mathrm{HPO}_{4}$ solution. With the $\mathrm{K}_{2} \mathrm{HPO}_{4}$ solution, $\mathrm{Ca}$ concentration slightly increased up to about $0.4 \mathrm{ppm}$ and was kept below $0.3 \mathrm{ppm}$ through the whole reaction.

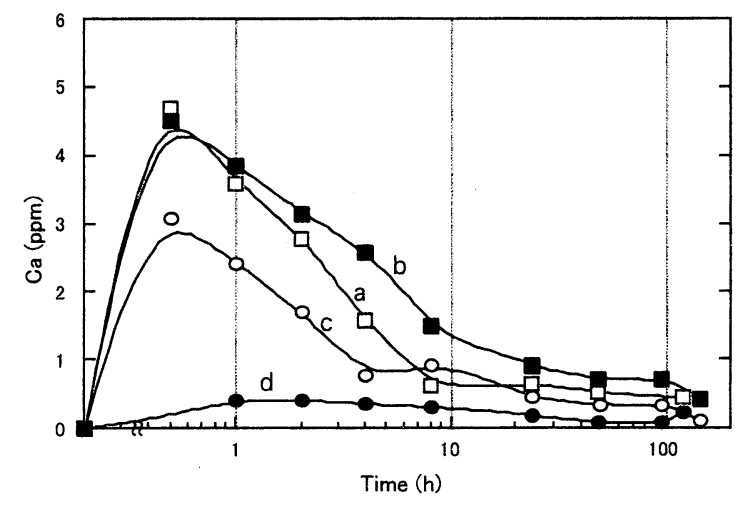

Figure 3 Change in $\mathrm{Ca}$ concentration with time during hydrolysis in the phosphate solutions. a: $0.1 \mathrm{~mol} / \mathrm{LKH}_{2} \mathrm{PO}_{4}, \mathrm{~b}: \mathrm{KH}_{2} \mathrm{PO}_{4} / \mathrm{K}_{2} \mathrm{HPO}_{4}=2 / 1$, c: $\mathrm{KH}_{2} \mathrm{PO}_{4} / \mathrm{K}_{2} \mathrm{HPO}_{4}=1 / 2$, d: $0.1 \mathrm{~mol} / \mathrm{LK}_{2} \mathrm{HPO}_{4}$ 
Figure 4 shows $\mathrm{X}$-ray diffraction patterns for the hydrolysis products in $0.1 \mathrm{~mol} / \mathrm{L} \mathrm{KH}_{2} \mathrm{PO}_{4}$ solution, which had a lowest $\mathrm{pH}$, at various times. A strong peak around $29^{\circ}$ was from 104 reflection of the original calcite. Its intensity decreased with time and the peak had almost disappeared after $48 \mathrm{~h}$. Another strong peak around $4-5^{\circ}$ showed the formation of octacalcium phosphate(OCP). Apatite (AP) phase also formed together with OCP. The peak intensity of OCP showed a maximum after $4 \mathrm{~h}$ and then decreased.

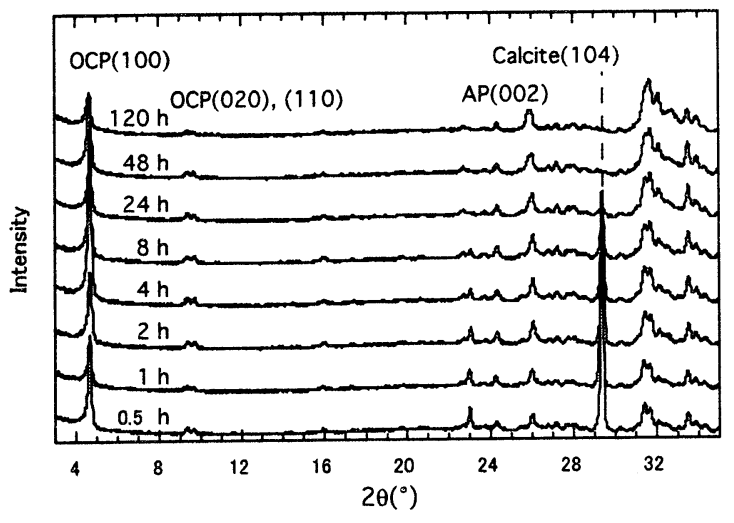

Figure $4 \mathrm{X}$-ray diffraction patterns for the hydrolysis products in $0.1 \mathrm{~mol} / \mathrm{L} \mathrm{KH}_{2} \mathrm{PO}_{4}$ solution at different time.

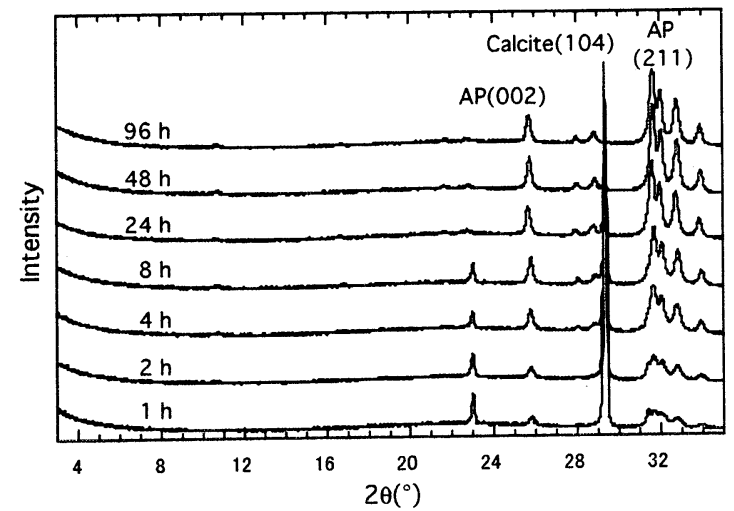

Figure $5 \mathrm{X}$-ray diffraction patterns for the hydrolysis products in $0.1 \mathrm{~mol} / \mathrm{L} \mathrm{K}_{2} \mathrm{HPO}_{4}$ solution at different time.

With decreasing in intensity of OCP, apatite phase increased. This fact suggested that apatite was partly formed through OCP. Figure 5 shows X-ray diffraction patterns for the hydrolysis products in 0.1 $\mathrm{mol} / \mathrm{L} \mathrm{K}_{2} \mathrm{HPO}_{4}$ solution, which had a highest initial $\mathrm{pH}$, at various times. OCP formation was not confirmed and apatite was exclusively formed during the hydrolysis. Thus calcite was directly transformed into apatite without OCP formation.

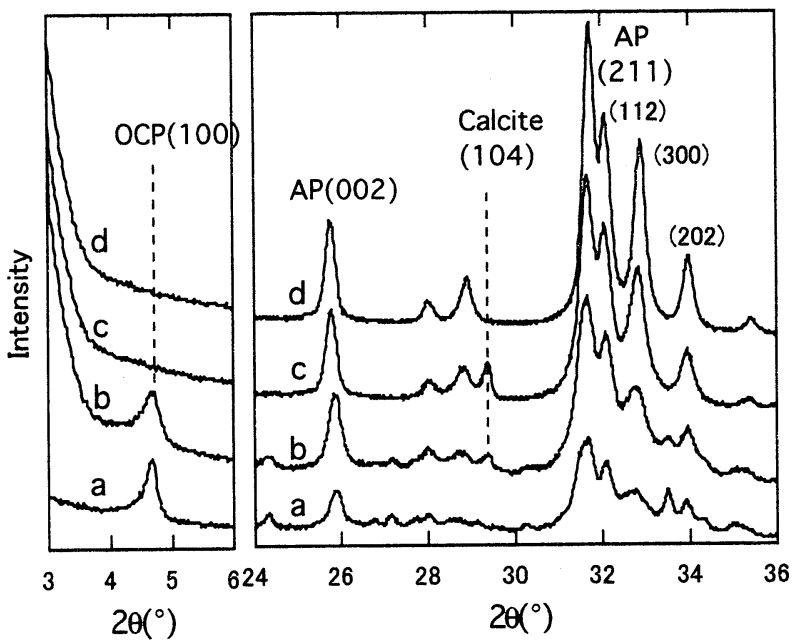

Figure $6 \mathrm{X}$-ray diffraction patterns for the final hydrolysis products in the phosphate solutions. $\mathrm{a}: 0.1 \mathrm{~mol} / \mathrm{LKH}_{2} \mathrm{PO}_{4}, \mathrm{~b}: \mathrm{KH}_{2} \mathrm{PO}_{4} / \mathrm{K}_{2} \mathrm{HPO}_{4}=2 / 1$, c: $\mathrm{KH}_{2} \mathrm{PO}_{4} / \mathrm{K}_{2} \mathrm{HPO}_{4}=1 / 2$, d: $0.1 \mathrm{~mol} / \mathrm{LK}_{2} \mathrm{HPO}_{4}$

Figure 6 shows X-ray diffraction patterns for the final hydrolysis products in the phosphate solutions. With the increase in $\mathrm{pH}$ of the solutions, that is, the amount of $\mathrm{K}_{2} \mathrm{HPO}_{4}$, OCP formed less and apatite predominantly formed as the final product. It was suggested that the two-step increase in $\mathrm{pH}$ corresponded to OCP formation and its transformation to apatite. It was also found that a small amount of unreacted calcite tended to remain in the solutions with medium $\mathrm{pH}$ range. Calcite completely disappeared in the solutions with the lowest and the highest $\mathrm{pH}$ within 4 days. The overall reaction rate seemed to depend on $\mathrm{pH}$ of the phosphate solutions. Lattice parameter of hexagonal apatite crystal in the final products was obtained by WPPF and is shown in Table 1.

Table 1 Lattice parameters of hexagonal apatite crystal and their $\mathrm{CO}_{3}$ content in the final products

\begin{tabular}{cccc}
\hline Solution & $\mathrm{CO}_{3}(\%)$ & $\mathrm{a}(\AA)$ & $\mathrm{b}(\AA)$ \\
\hline $0.1 \mathrm{~mol} / \mathrm{L} \mathrm{KH}_{2} \mathrm{PO}_{4}$ & 1.2 & - & - \\
$\mathrm{KH}_{2} \mathrm{PO}_{4} / \mathrm{K}_{2} \mathrm{HPO}_{4}=2 / 1$ & 4.6 & 9.452 & 6.887 \\
$\mathrm{KH}_{2} \mathrm{PO}_{4} / \mathrm{K}_{2} \mathrm{HPO}_{4}=1 / 2$ & 8.5 & 9.439 & 6.893 \\
$0.1 \mathrm{~mol} / \mathrm{L} \mathrm{K}_{2} \mathrm{HPO}_{4}$ & 8.0 & 9.426 & 6.897 \\
\hline
\end{tabular}

Figure 7 shows FT-IR spectra for the final hydrolysis products in the phosphate solutions. As found in X-ray diffraction analysis, the FT-IR spectra (a) showed co-existence of OCP and apatite phase in $0.1 \mathrm{~mol} / \mathrm{L} \mathrm{KH}_{2} \mathrm{PO}_{4}$ solution with the lowest initial $\mathrm{pH}$. With the increase in $\mathrm{pH}$ of the solutions, the spectra showed only the existence of apatite phase. 


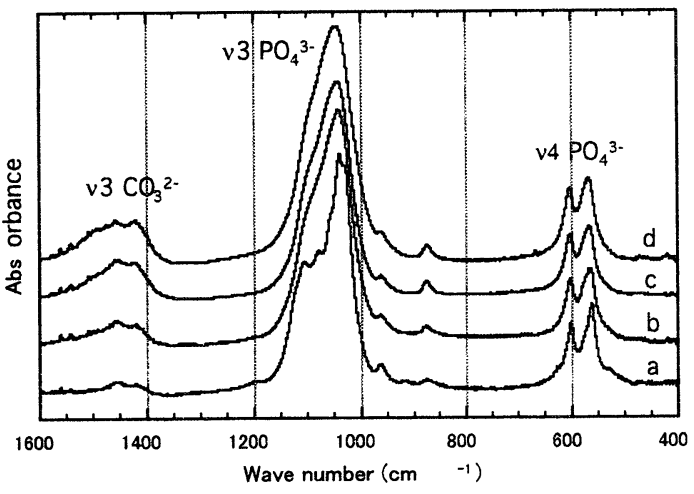

Figure 7 FT-IR spectra for the final hydrolysis products in the phosphate solutions.

a: $0.1 \mathrm{~mol} / \mathrm{LKH}_{2} \mathrm{PO}_{4}, \mathrm{~b}: \mathrm{KH}_{2} \mathrm{PO}_{4} / \mathrm{K}_{2} \mathrm{HPO}_{4}=2 / 1$,

c: $\mathrm{KH}_{2} \mathrm{PO}_{4} / \mathrm{K}_{2} \mathrm{HPO}_{4}=1 / 2$, d: $0.1 \mathrm{~mol} / \mathrm{LK}_{2} \mathrm{HPO}_{4}$

Absorption band around $1400-1450 \mathrm{~cm}^{-1}$, which was assigned to $v 3$ stretching vibration of $\mathrm{CO}_{3}{ }^{2-}$ ion, was found in the spectra. ${ }^{9,10}$ This fact suggested that the apatite formed was carbonated apatite. The band reveals formation of B-type carbonated apatite, in which $\mathrm{CO}_{3}{ }^{2-}$ ion substituted for $\mathrm{PO}_{4}{ }^{3-}$ ion in the apatite lattice. ${ }^{11,12}$ Featherstone et al. reported that $\mathrm{CO}_{3}$ content in carbonated apatite was calculated from the absorbance ratio of $\mathrm{CO}_{3}$ band at $1415 \mathrm{~cm}^{-1}$ $\left(A_{1415}\right)$ and the phosphate band at $575 \mathrm{~cm}^{-1}\left(A_{575}\right)$ in the FT-IR spectrum by the following equation. ${ }^{13}$

$$
\mathrm{CO}_{3} \text { content }(\mathrm{wt} \%)=16.1 \times\left(\mathrm{A}_{1415} / \mathrm{A}_{575}\right)-0.2
$$

Table 1 shows the $\mathrm{CO}_{3}$ content of the final hydrolysis products calculated from the eq.(1). The $\mathrm{CO}_{3}$ content increased with increasing in $\mathrm{pH}$ of the solutions. This is partly due to difference in the formation ratio of OCP to apatite in the final product phase.

Figure 8 shows the relationship between $\mathrm{CO}_{3}$ content and a-axis parameter in the apatite phase together with the data reported by LeGeros. ${ }^{14,15} \mathrm{~A}$ linear relation holds between a-axis and $\mathrm{CO}_{3}$ content expressed by the following equation.

$$
\text { a-axis }(\AA)=9.44-0.006 \mathrm{X}\left(\mathrm{CO}_{3} \mathrm{wt} \%\right)
$$

The lattice parameter (a-axis) obtained in the present study also seems to hold the same relation though the values are slightly larger than those. This fact may suggest that $\mathrm{K}^{+}$ion substitutes for $\mathrm{Ca}^{2+}$ ion in the apatite lattice because the former has a larger ionic radius than the latter. It was reported that substitution of $\mathrm{K}^{+}$ion for $\mathrm{Ca}^{2+}$ occurred in the hydrolysis of monetite or OCP to form $\mathrm{K}^{+}$-containing carbonated apatite. $^{16,17}$ Further study will be needed to elucidate the effect of the substitution on lattice parameters.

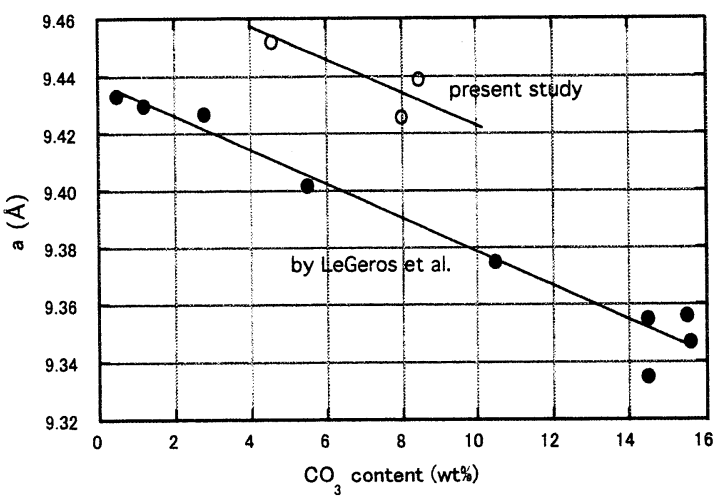

Figure 8 Relationship between $\mathrm{CO}_{3}$ content and a-axis parameter in the apatite formed.

Figure 9 shows SEM photographs of the products during hydrolysis in $0.1 \mathrm{~mol} / \mathrm{L} \mathrm{KH}_{2} \mathrm{PO}_{4}$ and 0.1 $\mathrm{mol} / \mathrm{L} \quad \mathrm{K}_{2} \mathrm{HPO}_{4}$ solutions. Original calcite crystal powder shows a distorted cuboid form. With 0.1 $\mathrm{mol} / \mathrm{L} \quad \mathrm{KH}_{2} \mathrm{PO}_{4}$ solution, thin plate-like OCP crystals are
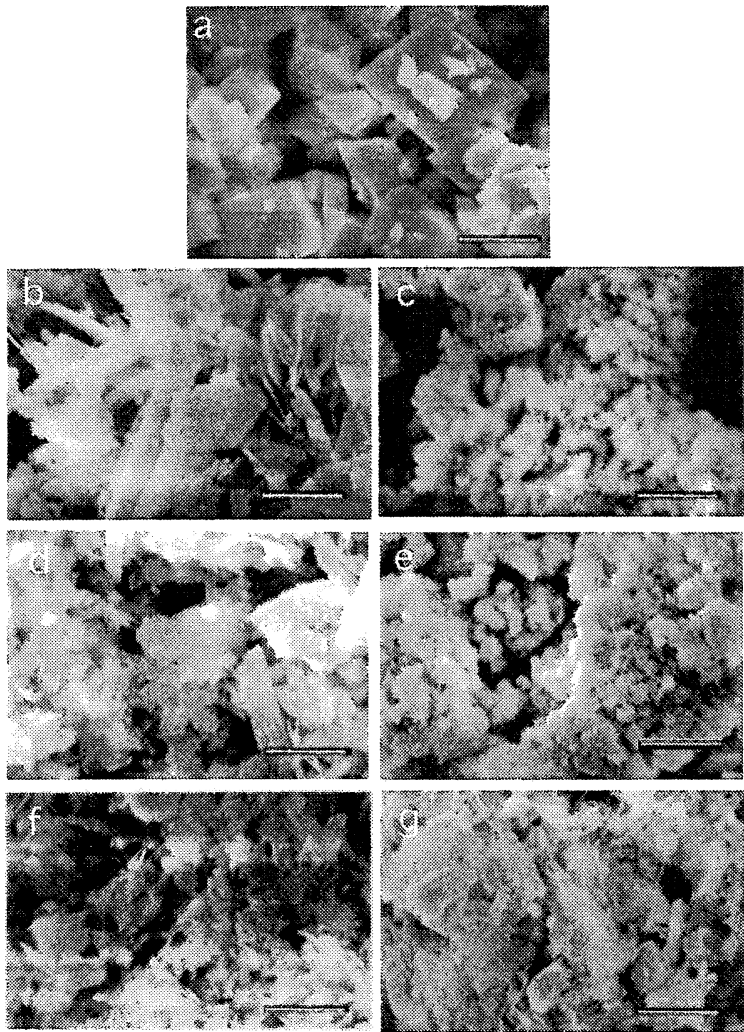

Figure 9 SEM photographs of the original calcite powder (a) and the products during hydrolysis in 0.1 $\mathrm{mol} / \mathrm{L} \mathrm{KH}_{2} \mathrm{PO}_{4}$ for $1 \mathrm{~h}$ (b) and $120 \mathrm{~h}(\mathrm{~d})$, in 0.1 $\mathrm{mol} / \mathrm{L} \mathrm{K}_{2} \mathrm{HPO}_{4}$ for $1 \mathrm{~h} \mathrm{(c)}$ and $96 \mathrm{~h}(\mathrm{e})$, in $\mathrm{KH}_{2} \mathrm{PO}_{4}$ $/ \mathrm{K}_{2} \mathrm{HPO}_{4}=2 / 1$ for $144 \mathrm{~h}(\mathrm{f})$ and in $\mathrm{KH}_{2} \mathrm{PO}_{4} / \mathrm{K}_{2} \mathrm{HPO}_{4}$ $=1 / 2$ for $144 \mathrm{~h}(\mathrm{~g})$. Bars in the figures show $5 \mu \mathrm{m}$. 
observed after $1 \mathrm{~h}$. The surface of the plate-like crystals became rough after 4 days. OCP was transformed into carbonated apatite with preserving its original outer shape (Fig9 b,d). This means that the carbonated apatite was formed through the topotactical reaction of OCP. On the other hand, with $0.1 \mathrm{~mol} / \mathrm{L} \mathrm{K}_{2} \mathrm{HPO}_{4}$ solution, OCP crystals are not observed as anticipated

by the results of XRD and very fine crystals are found through the raction (Fig9 c,e). From comparison of SEM photographs for the final hydrolysis products in

the phosphate solutions (Fig9 d-g), it was found that the plate-like crystals of OCP disappeared and fine particulate crystals were seen instead with the increase in $\mathrm{pH}$ of the solutions.

Solubility curves of calcite, OCP and hydroxyapatite (OHAp) are very helpful to understand the hydrolysis process. Figure 10 shows solubility curves of $\mathrm{Ca}$ plotted against $\mathrm{pH}$ for the three compounds calculated from their solubility products. ${ }^{18}$ Initial $\mathrm{pHs}$ of the solutions are also shown by vertical dashed lines in the figure. OHAp is the most stable phase and OCP phase is a pseudostable phase at $\mathrm{pH}$ between 3.5 and 9.5 among them. In the hydrolysis process, calcite first dissolved into the solution and $\mathrm{Ca}^{2+}$ ion and $\mathrm{CO}_{3}{ }^{2-}$ ion concentration increased. In the most acidic $\mathrm{KH}_{2} \mathrm{PO}_{4}$ solution with an initial $\mathrm{pH}$ of $4.5, \mathrm{Ca}^{2+}$ ion concentration became high due to high solubility of calcite at the $\mathrm{pH}$. As the reaction proceeded, $\mathrm{pH}$ of the solution increased up to 6.8 within $30 \mathrm{~min}$. Equilibrium solubility for $\mathrm{Ca}^{2+}$ ion was about $600 \mathrm{ppm}$ at the pH (Fig. 10). As simultaneous precipitation of OCP occurred, the actual concentration was increased only up to around $4.5 \mathrm{ppm}$ at $30 \mathrm{~min}$ as shown in Fig. 3. OCP solubility is about $8.3 \mathrm{ppm}$ of $\mathrm{Ca}^{2+}$ ion and OHAp solubility is about $1.8 \mathrm{ppm}$. The solution might have been supersaturated with respect to not only OHAp but also OCP and lead pseudostable OCP formation. As the OCP precipitated, $\mathrm{Ca}^{2+}$ ion concentration was further decreased after several hours as shown in Fig. 3. OCP would transform gradually into OHAp (carbonated apatite in this case) as a most stable phase with decreasing in $\mathrm{Ca}^{2+}$ ion concentration. With the increase in $\mathrm{pH}$ of the solutions, dissolution of calcite was limited and $\mathrm{Ca}^{2+}$ ion concentration would not increase to supersaturate with respect to OCP. Thus OCP would not form any more in the solution with high $\mathrm{pH}$ and calcite was transformed directly into OHAp without formation of OCP. It was reported that OCP was hydrolyzed to form OHAp in the presence of $\mathrm{Ca}^{2+}$ ion according to the following reaction. ${ }^{19}$

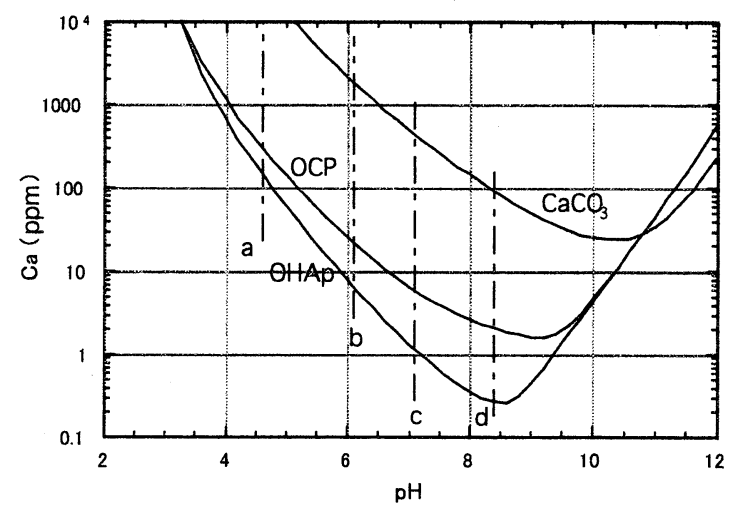

Figure 10 solubility curves of Ca plotted against $\mathrm{pH}$ for OHAp, OCP and $\mathrm{CaCO}_{3}$ (Calcite). Vertical dashed lines show the initial $\mathrm{pH}$ of the solutions. a: $0.1 \mathrm{~mol} / \mathrm{LKH}_{2} \mathrm{PO}_{4}, \mathrm{~b}: \mathrm{KH}_{2} \mathrm{PO}_{4} / \mathrm{K}_{2} \mathrm{HPO}_{4}=2 / 1$, c: $\mathrm{KH}_{2} \mathrm{PO}_{4} / \mathrm{K}_{2} \mathrm{HPO}_{4}=1 / 2$, d: $0.1 \mathrm{~mol} / \mathrm{LK}_{2} \mathrm{HPO}_{4}$

$$
\begin{aligned}
& \mathrm{Ca}_{8} \mathrm{H}_{2}\left(\mathrm{PO}_{4}\right)_{6} \cdot 5 \mathrm{H}_{2} \mathrm{O}+2 \mathrm{Ca}^{2+} \\
& \rightarrow \quad 2 \mathrm{Ca}_{5}\left(\mathrm{PO}_{4}\right)_{3} \mathrm{OH}+3 \mathrm{H}_{2} \mathrm{O}+4 \mathrm{H}^{+}
\end{aligned}
$$

This reaction seemed to occur similarly in the case of carbonated apatite formation. Proton evolution by the above reaction caused a decrease in $\mathrm{pH}$ observed at the later stage of the hydrolysis in the solution with low initial pH, as shown in Fig.1. Iijima et al. also reported OCP formation favored instead of AP when the speed of $\mathrm{Ca}^{2+}$ ion addition was increased in the solution with initial $\mathrm{Ca} / \mathrm{P}$ ratio between $0.043-0.14{ }^{20}$ They concluded that an appropriate addition speed was necessary to maintain the degree of supersaturation to OCP. The result of the present study well agrees with their observation.

\section{CONCLUSION}

Hydrolysis of calcite was investigated in potassium phosphate solutions with various $\mathrm{pHs}$ between 4.5 and 8.4. Calcite was mostly hydrolyzed in the solutions within several days and the final product was OCP or apatite phase depending on their initial pHs. OCP was initially formed in the solution with lower $\mathrm{pH}$ and it was transformed into apatite phase with increasing in $\mathrm{pH}$. Calcite was directly transformed into apatite in $0.1 \mathrm{~mol} / \mathrm{L} \mathrm{K}_{2} \mathrm{HPO}_{4}$ solution with the highest initial $\mathrm{pH}$. This phenomenon was probably related to solubility of apatite, OCP and calcite at $\mathrm{pH}$ during hydrolysis. FT-IR analysis showed that the apatite phase formed was B-type carbonated apatite, in which $\mathrm{CO}_{3}{ }^{2-}$ ion substituted for $\mathrm{PO}_{4}{ }^{3-}$ ion. 
Matsuya S, Udoh K, Nakagawa M, Ishikawa I

\section{ACKNOWLEDGEMENT}

This study was supported in part by a grant-in-aid for Scientific Research from the Ministry of Education, Culture, Sports, Science and Technology.

\section{REFERENCES}

1. R.T.Chiroff , E.W. White, K.N.Weber, D.M.Roy, J. Biomed. Mater. Res., 9, 29(1975)

2. D.M.Roy, S.K.Linnehan, Nature,246, 220 (1974).

3. M.Sivakumar, T.S.Kumar, K.L.Shantha, K.P.Rao, Biomaterials, 17, 1709 (1996).

4. W.Suchanek, M.Yoshimura, J. Mater. Res. 13, 94 (1998).

5. R. Holmes, Plast. Reconstr. Surg., 63, 626(1979).

6. L.L. Ames, Jr., Economic Geol., 54, 829(1959).

7. D.R. Simpson, Am. Mineral., 52, 896(1967).

8. H. Monma, T. Takahashi, Gypsum \& Lime, No 210, 29(1987).

9. R.Z. LeGeros, O.R. Trautz, J.P. LeGeros, E. Klein, Bull. Soc. Chim. Fr., 1712 (1968).
10. C. Rey, B. Collins, T. Goehl, I.R. Dickson, M.J. Glimcher, Calcif. Tissue Int., 45, 157(1989).

11. G.Bonel, G. Montel, Comptes rendus, 258, 923(1964).

12. M.Vignoles, G. Bonel, D.W. Holocomb, R.A. Young, Calcif. Tissue Int., 43, 33(1988).

13. J.D. Featherstone, S. Pearson, R.Z. LeGeros, Caries Res. , 18(1), 63-(1984).

14. R. Z. LeGeros, Nature, 206, 403 (1965).

15. R.Z. LeGeros, M.S.Tung, Caries Res., 17, 419(1983).

16. E.A.P. de Meyer, R.M.H.Verbeeck, I.Y.Pieters, J. Cryst Growth, 169, 539 (1996).

17. I.Y.Pieters, E.A.P. de Meyer, R.M.H.Verbeeck, Inorg. Chem., 35, 5791 (1996).

18. G.Vereecke, J. Lemaitre, J. Cryst. Growth, 104, 820 (1990).

19. W.E. Brown, M. Mathew, M.S. Tung, Prog. Crystal Growth Charact., 4, 59 (1981).

20. M.lijima, H. Kamemizu, N. Wakamatsu, T. Goto, Y. Doi, Y. Moriwaki, J. Cryst Growth, 193, 182 (1998). 